\title{
Analiza i ocena metod oraz narzędzi badawczych: doniesienie z badania pilotażowego dotyczącego obrazu Innego konstruowanego przez polskich trzecioklasistów
}

\author{
SANDRA KWAŚNIEWSKA-PASZTA ${ }^{1}$ \\ ${ }^{1}$ Uniwersytet Warszawski, Wydział Pedagogiczny, ul. Mokotowska 16/20, 00-651 Warszawa. ORCID: \\ 0000-0001-5164-5763, Email: sandrakwasniewska511@gmail.com
}

STRESZCZENIE: W artykule zostaje przedstawiona analiza oraz ocena narzędzi badawczych wykorzystanych w badaniu pilotażowym, dotyczącym zagadnienia obrazu Innego konstruowanego przez uczniów klas trzecich. Obraz ten ściśle związany jest z określeniem stosunku dzieci do Innego, m.in. poprzez ustalenie ich dystansu społecznego wobec grup innych kulturowo. Badanie to miało charakter mieszany i zawierało zarówno ujęcie jakościowe jak i ilościowe. Ponadto artykuł ma na celu zwrócenie uwagi na istotną kwestię postrzegania Innego kulturowo przez uczniów klas młodszych w kontekście tematyki wielokulturowości jako wyzwania współczesnej polskiej szkoły¹. SŁOWA KLUCZOWE: Obraz Innego, edukacja wczesnoszkolna, wielokulturowość, wyzwania współczesnej edukacji, badanie pilotażowe

\section{WPROWADZENIE}

Artykuł ten ma na celu dokonanie wnikliwej oceny oraz analizy zastosowanych narzędzi badawczych w badaniu pilotażowym dotyczącym zagadnienia konstruowania obrazu Innego przez uczniów kończących edukację wczesnoszkolną. Niniejsze opra-

\footnotetext{
${ }^{1}$ Jest to artykuł z dorobku przygotowywanej dysertacji pod kierunkiem prof. dr hab. Małgorzaty Żytko oraz dr Urszuli Markowskiej-Manisty.
} 
cowanie stanowi próbę zasygnalizowania problemu oraz zakreślenia jego terenu badawczego. Nie ulega wątpliwości, że wielokulturowość stanowi obecnie palące wyzwanie współczesnej polskiej edukacji. Wobec tego problemu nie należy przechodzić obojętnie. Artykuł ten kierowany jest w sposób szczególny do doktorantów, pracowników uczelni wyższych lub pracowników oświaty, którzy planują przeprowadzanie badań o podobnej tematyce wśród uczniów edukacji wczesnoszkolnej.

\section{WIELOKULTUROWOŚĆ WYZWANIEM WSPÓŁCZESNEJ EDUKACJI}

W ostatnich latach miały miejsce dynamiczne zmiany społeczne, gospodarcze, ekonomiczne i polityczne, które zaszły zarówno w Europie, jak i na świecie. Wśród procesów, które przyczyniły się do wspomnianych powyżej zmian wymienić możemy chociażby faleę migracji, która z kolei przyczyniła się do zwiększenia na tym terytorium liczby grup mniejszościowych etnicznie (Kubiszyn 2007).

Fakt iż, migracje stają się zjawiskiem, które narasta ma związek zarówno z mobilnością ludzi w obszarze osobistym i zawodowym jak i z nieustannym rozwojem technologicznym. W tym miejscu warto także podkreślić, że przemieszczanie się ludzi na świecie nie ogranicza się jedynie do tworzenia przepływów demograficznych, ale stanowi istotny czynnik, który wpływa na nasz zglobalizowany świat (Balicki 2015). Ze względu na masowy charakter migracji, co potwierdza liczba 1,3 miliona wniosków o azyl w Unii Europejskiej w 2015 roku, zjawisko to stanowi ważny problem polityki międzynarodowej. Różnice kulturowe oraz duża liczba imigrantów napływająca do społeczeństw przyjmujących mogą prowadzić do szoku kulturowego i idącej za nim niechęci wobec przybyszów (Markowska-Manista 2017). W związku z intensywnymi migracjami nowożytna historia wyróżnia się niespotykaną jak dotąd skalą różnorodności kulturowej, religijnej oraz etnicznej. Jak wykazał Piotr Wojnicz, jedynie dwadzieścia na dwieście państw na świecie wyróżnia się monoetnicznością, czyli zdecydowaną dominacją jednej grupy etnicznej. Z kolei kontynent europejski charakteryzuje się maksymalizacją wspomnianej różnorodności na przestrzeni, która jest stosunkowo niewielka (Wojnicz 2003).

Wielokulturowość w węższym zakresie odnosi się do różnorodności kulturowej, natomiast w zakresie szerszym dotyczy wieloetnicznego koegzystowania w państwie demokratycznym, afirmującym wartości takie jak równość, wolność, tolerancja, poszanowanie indywidualizmu. Wielokulturowość to pojęcie, które koncentruje się nie tylko na mniejszościach wyznaniowych oraz narodowych, ale także określonych grupach społeczno-ekonomicznych (Kubiszyn 2007). W tym sensie należy powiedzieć, że niezależnie od tego, iż polskie społeczeństwo cechuje się niskim zróżnicowaniem kulturowym w porównaniu do krajów Zachodniej Europy to jednak problematyka wielokulturowości coraz intensywniej go dotyczy (Szplit 2013).

Według Johna Berry’ego oraz Davida Sama w przeważającej części społeczeństw wielokulturowość postrzega się jedynie jako fakt demograficzny. Oznacza to, że w takich społeczeństwach zjawisko wielokulturowości sprowadza się do obecności wielu grup etnokulturowych bez uwzględnienia interakcji międzykulturowych. Wielu praktyków oraz teoretyków upatruje w powyższym dyskursie społecznym tzw. porażkę 
wielokulturowości. Uważa się, że niewdrażanie polityki równościowej oraz tolerancja istnienia różnych kultur może w konsekwencji doprowadzić zarówno do segregacji społeczeństwa jak i wykluczenia mniejszości kulturowych (Berry 2013).

W obliczu powyższych rozważań należy zwrócić uwagę na to, że dyskusja dotycząca zjawiska wielokulturowości nie należy do łatwych, ponieważ wielu krytyków postrzega ją jako zróżnicowanie demograficzne, a nie zróżnicowanie kulturowe. Ponadto często zdarza się, że wielokulturowość utożsamiana jest z relatywizmem kulturowym, który ściśle związany jest z usprawiedliwianiem praktyk kulturowych niezależnie od tego jakie prawo oraz obyczaje panują w danym państwie (Berry 2013).

W krajach zachodu demograficzne zróżnicowanie kulturowe jest dużo większe niż w Polsce, jednak mimo to, zagadnienie to coraz mocniej dotyczy naszego kraju (Mihułka 2008). Według Beaty Gromadzkiej Polska mierzy się ze zjawiskiem wielokulturowości od wielu lat. Jako uzasadnienie powyższego stanowiska autorka podaje przykład sytuacji mniejszości romskiej w Polsce. W odróżnieniu od relacji z mniejszościami, które relatywnie niedawno przybyły do naszego kraju, takimi jak Wietnamczycy, Chińczycy czy Ukraińcy, stosunki z Romami naznaczone są trudnościami wynikającymi z przeszłych lat koegzystencji, narosłych stereotypów czy antagonizmów. Autorka zauważa, że przy decyzjach dotyczących sposobów postępowania z nowymi falami imigrantów Polacy biorą pod uwagę efekty działań swoich zachodnich sąsiadów i łatwiej jest im budować z nimi relacje międzyludzkie (Gromadzka 2016).

$Z$ drugiej jednak strony warto zwrócić uwagę na fakt, że pomimo jednolitej struktury narodowo-wyznaniowej w Polsce, napływa do naszego kraju coraz więcej migrantów. Ponadto nasila się niechęć polskiego społeczeństwa wobec imigrantów, w szczególności tych, którzy pochodzą spoza europejskiego kręgu kulturowego (Barwiński 2016). Jesteśmy obecnie świadkami nasilonej dyskusji wewnątrz Polski, pomiędzy zwolennikami i przeciwnikami przyjmowania imigrantów, którego wynik nie jest przesądzony (Markowska-Manista 2016). Nie ulega wątpliwości, że zróżnicowanie kulturowe stanowi wyzwanie dla współczesnego świata, a przede wszystkim dla edukacji (Mihułka 2008).

Kształtowanie u dziecka przekonania o tym, iż każdy człowiek jest inny to bardzo istotna kwestia w obliczu opisanych powyżej przemian społeczno-kulturowych. Jest to również jeden $\mathrm{z}$ ważnych celów edukacji międzykulturowej. Ponadto ważne jest tutaj podkreślenie, że inność jest wartościowa, godna szacunku i może być ciekawa poznawczo. Dzięki takiemu przekonaniu możliwa staje się pozytywna zmiana stosunku do ludzi np. innych kulturowo. Kształtowanie wrażliwości i otwartości na Innego - szczególnie w najbliższym otoczeniu dziecka, czyli rzeczywistości przedszkolnej, szkolnej, lokalnej czy środowiska domowego stwarza solidne podstawy do zainteresowania się Innym (Szostak-Król, 2004).

Inny, jak podaje słownik języka polskiego, określany jest jako dalszy, odmieniony, zmieniony lub drugi. Ponadto inność to pojęcie odnoszące się do osób funkcjonujących w tych samych grupach społecznych, w ramach których wyraźnie się odróżniają (Welskop 2014). Na postrzeganie tych osób wpływ ma m.in. kategoryzacja o charakterze społecznym, wynikająca ze schematów poznawczych, skryptów, stereotypów oraz wiedzy potocznej (Markowska-Manista 2016). W sytuacji gdy Inny postrzegany jest 
w sposób negatywny a jego odmienność wywołuje obawy, staje się on Obcym. Pozytywna bądź negatywna ocena wyznacza granicę między obcością a innością (Welskop 2014). Obecność Obcych może powodować u ludzi obawy i lęk, które w konsekwencji doprowadzają do tego, że nie dostrzegają oni potencjału i możliwości, jakie grupy odmienne kulturowo mogłyby dać społeczeństwu (Markowska-Manista 2016). Kwestia stosunku dzieci do Innego nabiera obecnie szczególnego znaczenia, biorąc pod uwagę coraz bardziej nasilone zjawisko zróżnicowania kulturowego.

Należy również podkreślić, że jednostka podczas procesu uczenia się jest aktywna i tworzy określone konstrukty, zwane inaczej obrazami rzeczywistości. Na to jak dany konstrukt wygląda ma wpływ zarówno aspekt kulturowy, biograficzny oraz poznawczy jednostki. Wytworzone przez uczniów reprezentacje rzeczywistości stają się podwaliną procesu interpretacyjnego nowych sytuacji. Biorąc pod uwagę pełny kontekst sytuacyjny danego pojęcia, uczniowie nadają rzeczywistości określone znaczenie (Klus-Stańska 2009). Proces jego nadawania tworzy się za pomocą interakcji, a język to narzędzie komunikowania, rozumienia i konstruowania rzeczywistości. Warto nadmienić, iż konstruowanie wiedzy przez dziecko sprawia, że rozwija ono umiejętności takie jak: tworzenie i negocjowanie znaczeń, stawianie i weryfikacja hipotez, analizowanie i rozwiązywanie problemów oraz krytyczne myślenie (Nowak-Łojewska 2017). Szkoła stanowiąc coraz częściej miejsce styku różnych kultur wymaga od kadry pedagogicznej odpowiedniego przygotowania. Poza wiedzą dotyczącą różnic kulturowych, nauczyciele powinni rozumieć ich wpływ na sposoby uczenia się, rozumienia świata, interpretacji zachowań innych ludzi oraz posiadać umiejętność zapobiegania postawom ksenofobicznym oraz etnocentrycznym (Badowska 2015). Kompetencje międzykulturowe pedagogów nabierają szczególnego znaczenia w czasach opisanych wcześniej przemian społecznych, gdyż przygotowują do nich dzieci oraz młodzież. W dłuższej perspektywie czasu może to zaowocować bardziej otwartym, pokojowym i nastawionym na porozumienie dialogiem międzykulturowym całego społeczeństwa (Dąbrowa 2018).

\section{PODSTAWY METODOLOGII BADANIA PILOTAŻOWEGO}

Badanie pilotażowe stanowi rodzaj badania o charakterze wstępnym. Jego celem jest zarówno przetestowanie jak i ocena narzędzi badawczych, które mają zostać wykorzystane w badaniu zasadniczym. Definicji badania pilotażowego jest wiele i często nie są one explicite objaśnione. Rzadko zdarza się, że pilotaż dotyczy oceny dyrektyw koncepcyjnych odnoszących się np. do poprawnego doboru wskaźników. Niewątpliwie jednak, wszelkie decyzje dotyczące tej kwestii mają znaczący wpływ na użyteczność danych narzędzi w realizacji postawionych celów (Grzeszkiewicz-Radulska 2012). Najczęściej jedną z głównych funkcji badania pilotażowego jest kontrola przydatności metod oraz narzędzi badawczych, które zostaną wykorzystane w określonym środowisku. Przykładem będzie sprawdzenie przez badacza przydatności kwestionariusza np. w kwestii rozumienia zamieszczonych w nich pytań przez badanych (Nowak 2012). W kontekście powyżej opisanych funkcji badania pilotażowego istotne jest zwrócenie uwagi na brak znaczenia statystycznego wyników. 
W badaniu pilotażowym Inny rozumiany jest jako jednostka odmienna kulturowo. Odmienność w obszarze kulturowym odnosi się do innej narodowości, języka, wartości, idei, zwyczajów oraz tradycji. Świadomość nauczycieli dotycząca konstruowanego obrazu Innego przez uczniów jest ważna ze względu na działania dydaktyczno-wychowawcze podejmowane przez kadrę pedagogiczną. Diagnoza konstruowanego obrazu Innego uczniów mogłaby także pomóc w określeniu konkretnych aspektów edukacji międzykulturowej, które wymagają szczególnego namysłu oraz wprowadzenia w praktykę edukacyjną szkoły. Proces konstruowania wiedzy to cenne doświadczenie dla nauczycieli, którzy mogą w ten sposób poznać lepiej swoich uczniów, ich doświadczenia poznawcze, biograficzne, kulturowe oraz proces myślenia i tworzenia wiedzy (Badowska 2015). Dzięki tej wiedzy oraz doświadczeniom nauczyciele mogą organizować środowisko uczenia się w taki sposób, by możliwie jak najlepiej kierować procesem dydaktyczno-wychowawczym swoich podopiecznych. Na badanie pilotażowe przeznaczono czterdzieści pięć minut, a więc jedną godzinę lekcyjną. Celem badania jest uzyskanie odpowiedzi na problemy i pytania badawcze. Treść głównych problemów badawczych to:

Jak dzieci kończące I etap edukacji w szkole podstawowej postrzegają Innego kulturowo? Jaki dystans społeczny wykazują wobec niego? Czy Inny jest utożsamiany z Obcym?

Z kolei pytania szczegółowe brzmią następująco:

Kogo dzieci w wieku wczesnoszkolnym określają jako Innego? Jakie cechy mu przypisują?

Jak dzieci charakteryzują Innego/Obcego odmiennego kulturowo?

Jak dzieci określają relacje Innego z rówieśnikami i kolegami?

Jak dzieci charakteryzują szkołę i swoją klasę jako miejsce spotkania z Innym?

Jaki rodzaj dystansu społecznego w zakresie dwustopniowej skali (wyrażającej sprzeciw oraz akceptację wobec danej sytuacji) charakteryzuje stosunek dzieci w wieku wczesnoszkolnym do Innego?

Jaki stosunek mają dzieci do stałej obecności przedstawicieli Innych w mieście, w którym mieszkają?

Jaki stosunek mają dzieci do uczenia się w tej samej szkole z Innym?

Jaki stosunek mają dzieci do sąsiadowania z Innym w szkolnej ławce?

Jaki stosunek mają dzieci do spędzania wolnego czasu poza szkołą z Innym?

W badaniu zostało zastosowane podejście mieszane z wykorzystaniem metody jakościowej oraz ilościowej. Połączenie badań jakościowych oraz ilościowych zapewnia większe zrozumienie danego problemu badawczego. Tym samym można stwierdzić, 
że badania mieszane wykorzystują zarówno zalety ujęcia jakościowego jak i ilościowego. Wybraną przeze mnie strategią badań była równoległa strategia triangulacyjna, której schemat widoczny jest poniżej.

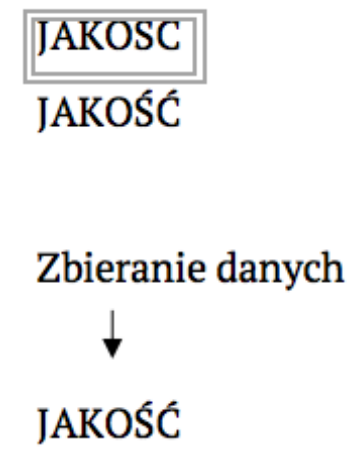

Analiza danych
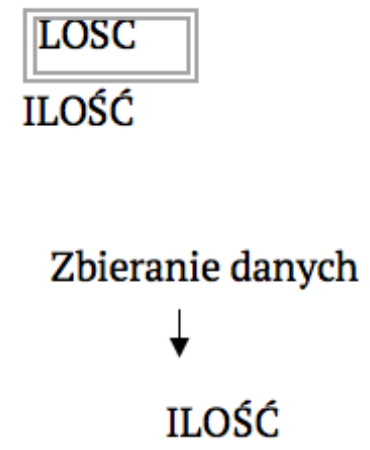

Analiza danych

Rycina 1.

Źródło: Opracowanie według Creswell i in. (2003)

Równoległa strategia triangulacyjna to najbardziej znany model badań mieszanych, który polega na jednoczesnym gromadzeniu danych jakościowych oraz ilościowych, a także porównywaniu obu źródeł po to, aby stwierdzić wszelkiego rodzaju różnice, powiązania oraz zbieżności między nimi. Są to niewątpliwie atuty tradycyjnego badania mieszanego, ponieważ zarówno dane ilościowe jak i jakościowe są równocześnie pozyskiwane w określonym miejscu badania, co ściśle wiąże się z krótszym czasem ich gromadzenia. W opisywanym modelu przeważnie stosuje się osobno zarówno metody jakościowe jak i ilościowe w celu łączenia mocnych stron obu metod bądź rekompensowania słabości jednej metody, mocnymi stronami drugiej. W praktyce często zdarza się, że jednej z metod przypisuje się priorytet, choć wskazane jest, aby obie metody traktować jako równorzędne. Ponadto należy nadmienić, iż równoległa strategia triangulacyjna jest znana i chętnie stosowana przez większość badaczy rozważających realizację metodologii badań mieszanych (Creswell 2013).

Do zrealizowania zamierzonych celów w ramach badań jakościowych wykorzystałam metodę zogniskowanego wywiadu grupowego. Wywiad miał charakter narracyjny i został uzupełniony o metodę wizualizacji. Finalnym punktem badania jakościowego było stworzenie przez uczniów autorskiego obrazu Innego.

Wywiad narracyjny jest wykorzystywany w badaniach jakościowych, których fundamentem jest konstruktywizm społeczny, występujący bardzo często wraz z interpretatywizmem. Konstruktywiści społeczni uznają, że zrozumienie otaczającego świata jest możliwe poprzez nadawanie subiektywnych znaczeń własnym doświadczeniom. W tym rozumieniu badacz stara się formułować otwarte pytania, które umożliwiają poznanie opinii oraz poglądów uczestników badania, konstruowanie znaczeń w sytuacji dyskusji oraz interakcji z innymi jednostkami (Badowska 2015). W przypadku wywiadu narracyjnego badacz nie narzuca struktury wypowiedzi badanemu, stara się nie ingerować w jej treść oraz formę. Jego zadaniem jest opis oraz interpretacja uzy- 
skanych danych (Kozerska).

Punktem wyjścia do wspomnianego wywiadu była prezentacja zdjęć dotyczących Innego. Zdjęcia te przedstawiały m.in. dzieci oraz dorosłych z innych kręgów kulturowych, ich zwyczaje oraz tradycje, ze wskazaniem, że są to przykłady.

W badaniach jakościowych analiza materiałów wizualnych została uznana za podejście o charakterze znaczącym. Materiały te uzyskują status danych ze względu na fakt poddawania ich analizie i bardzo często stosowane są wraz z werbalnymi metodami (Banks 2013). Przykładem będzie wywiad na podstawie zdjęć. W tym wypadku rola badacza ma charakter aktywny, ponieważ dokonuje on selekcji obrazów, które w późniejszym etapie służą do oglądania. Wykorzystywanie zdjęć podczas wywiadu ma na celu wywołanie dyskusji, wspomnień oraz komentarzy. Przykłady wybranych zdjęć stanowią pretekst do rozmowy dotyczącej szerszych i abstrakcyjnych zagadnień (Banks 2013).

Analiza wypowiedzi uczniów została dokonana na podstawie zarejestrowanych informacji z wywiadu w formie sporządzania notatek. Analiza ta miała na celu odtworzenie oraz zrozumienie subiektywnych struktur sensu, a więc poznanie oraz wyjaśnienie sposobu myślenia i podejścia do Innego kulturowo przez badanych. W trakcie dokonywania wspomnianej analizy szczególną uwagę zwróciłam na rozpoznawanie regularnie pojawiających się schematów, które służą badanym do określonego działania oraz tworzenia sensu swoich wypowiedzi (Kozerska).

Ponadto w badaniu pilotażowym wykorzystałam również metodę sondażową, która była badaniem przekrojowym, a więc takim, w którym dane zbierane są w jednym czasie. Metoda sondażowa reprezentuje rodzaj badania ilościowego (Kozerska).

W omawianym badaniu narzędziem, które zostało wykorzystane był kwestionariusz ankiety opartej na skali dystansu społecznego Bogardusa. Pozwolił on ustalić dystans społeczny uczniów wobec Innych.

Do nauk społecznych narzędzie to zostało wprowadzone przez E. Bogardusa w 1933 roku. Dystans społeczny stanowi miarę akceptowalnej bliskości względem osób, które różnią się pod względem określonej cechy np. pochodzenia etnicznego. Wskaźnik dystansu społecznego określa się na podstawie pytań dotyczących hipotetycznej relacji pomiędzy badanym, a przedstawicielem innej grupy. Respondent jest uznawany za bardziej otwartego i tolerancyjnego, jeśli odpowie pozytywnie na więcej pytań ułożonych według skali narastającego dyskomfortu. Oznacza to, że charakter skali jest kumulatywny (Jasińska-Kania 2009).

Merytoryczny aspekt kwestionariusza został dostosowany do potrzeb przygotowanych przeze mnie badań. W oparciu o cztery podstawowe sfery życia powstanie czterostopniowa skala badania:

(i) stała obecność przedstawicieli Innych w Warszawie - sfera makrospołeczna,

(ii) uczestniczenie w procesie uczenia się w tej samej szkole z Innym - sfera mikrospołeczna,

(iii) sąsiadowanie z Innym w szkolnej ławce - sfera prywatna, 
(iv) spędzanie wolnego czasu poza szkołą z reprezentantem grupy innej kulturowo/wyznaniowo - sfera intymna.

Narzędzie implementowało dwustopniową skalę, która wyrażała sprzeciw lub akceptację wobec danej sytuacji. Zebrane dane liczbowe zostały przedstawione jako procent dzieci wyrażających akceptację dla obecności Innego w poszczególnych sferach społecznych.

\section{ANALIZA ORAZ OCENA NARZĘDZI BADAWCZYCH}

Badanie pilotażowe zostało przeprowadzone w maju 2019 roku w jednej z prywatnych szkół podstawowych na warszawskim Wilanowie. Ostatecznie w badaniu uczestniczyło pięcioro dzieci z klasy III. Ze względu na małą liczebność klasy i tym samym w trosce o anonimowość uczniów nie ujawniona zostaje nazwa placówki. Zgody rodziców na udział uczniów w badaniu zostały zebrane przez nauczyciela-wychowawcę. Wnioski uzyskane po przeprowadzonym warsztacie były niezwykle wartościowe i satysfakcjonujące. Praca z pięcioosobową grupą uczniów pozwoliła na dokonanie skrupulatnej analizy oraz oceny metod i narzędzi badawczych wykorzystanych w pilotażu.

W zakresie badania jakościowego uczniowie trzecich klas zostali zaproszeni do wzięcia udziału w warsztacie pt. „Podróż z pluszowym misiem po Europie i Azji”. Warsztaty rozpoczęły się od przedstawienia uczniom pacynki - pluszowego misia, który stał się przewodnikiem uczniów po siedmiu krajach dwóch kontynentów - Europy i Azji.

Na prezentacji multimedialnej przedstawiono uczniom trzy zdjęcia, które ukazywały:

(i) przykładowy strój tradycyjny danego kraju/grupy etnicznej,

(ii) dwie fotografie grupy etnicznej/mieszkańców kraju w codziennych sytuacjach (w dużym mieście oraz poza nim).

Zadaniem dzieci było zgadnąć z jakiego kraju/grupy etnicznej pochodzą powyższe zdjęcia. Po każdej prezentacji nauczyciel dokonywał wywiadu z dziećmi. Podczas wspomnianego wywiadu pojawiły się następujące pytania:

Czy ktoś z Was odwiedził kiedyś ten kraj/spotkał osoby pochodzące z danej grupy etnicznej?

Czy mieliście okazję poznać osobiście mieszkańców tego kraju/osoby pochodzące $\mathrm{z}$ danej grupy etnicznej?

Czy chcielibyście się podzielić jakąś niezapomnianą historią związaną z Waszym pobytem w tym kraju/spotkaniem z grupą etniczną?

Czy ktoś z Was poznał obywatela tego kraju/osobę pochodzącą z grupy etnicznej w Polsce? Czy zaprzyjaźniliście się?

Czy oglądacie bajki bądź programy telewizyjne i radiowe, które opowiadają o innych kulturach? Jeśli tak to jakie? 
Czy czytacie książki, które opowiadają o innych kulturach?

Ponadto uczniowie zostali poproszeni również o wybranie jednego słowa-skojarzenia dotyczącego danej grupy etnicznej oraz danego kraju i jego mieszkańców, a także zapisanie go na kartce. Chętni uczniowie mogli podzielić się swoimi skojarzeniami na forum grupy. Kolejnym ćwiczeniem było wcielenie się uczniów w rolę dziennikarzy. Trzecioklasiści zostali poproszeni o zapisanie na kartkach pytań bądź przemyśleń skierowanych do danej grupy etnicznej oraz mieszkańców danego kraju.

Ostatnim zadaniem w zakresie badania jakościowgo było stworzenie przez uczniów rysunku pt. „Ja z kolegą/koleżanką z innego kraju/grupy etnicznej”. Uczniowie zostali poproszeni o narysowanie rysunku na powyżej przedstawiony temat w wybranej przez siebie sytuacji, miejscu oraz czasie.

W tym miejscu wartorównież dodać,że badanie to zostało uprzednio przeprowadzone z czternastoma studentami Wydziału Pedagogicznego Uniwersytetu Warszawskiego i uzupełnione o późniejszą wnikliwą analizę metod oraz narzędzi wykorzystanych w badaniu. Na podstawie analizy przeprowadzonego badania ze studentami, okrojono liczbę wybranych krajów i grup etnicznych z 12 do 7 ze względu na to, że wyższa ich liczba wiązała by się ze znacznym wydłużeniem czasu badania. Ponadto usunięto również jedno ćwiczenie, które polegało na układaniu przez uczniów puzzli z flagą danego państwa bądź grupy etnicznej oraz przymocowaniu powstałego obrazka na mapie świata. Ćwiczenie to, choć uznane przez studentów za atrakcyjne oraz wartościowe w sensie poznawczym również musiało zostać wyeliminowane ze względu na ograniczenie czasu trwania badania. Poza tym scenariusz warsztatów uzupełniono o wprowadzenie uczniów w tematykę zajęć poprzez szczególne zwrócenie uwagi na wytłumaczenie im takich pojęć jak: kraj, narodowość, a także grupa etniczna. Wyrażono pełną zgodę, że wyjaśnienie uczniom wspomnianych pojęć nie tylko systematyzuje bądź dostarcza im nowej wiedzy, ale również jest kluczowe dla zrozumienia i poprawnego wykonania poleceń w większości ćwiczeń. Z kolei dyskusyjną sprawą okazało się wykorzystanie pacynki podczas warsztatów. Według niektórych studentów mogła być ona postrzegana jako infantylna i przez to nieinteresująca dla dzieci kończących edukację wczesnoszkolną. Ostatecznie hipoteza ta potwierdziła się na co wskazują reakcje dzieci opisane w dalszej części rozdziału.

Niewątpliwie przeprowadzenie warsztatu ze studentami przed badaniem pilotażowym miało istotny wpływ na ostateczną treść scenariusza. Wszelkie uwagi oraz wysunięte wnioski pozwoliły na wyeliminowane różnych problemów związanych z badaniem, przede wszystkim jego ograniczenia czasowego.

Dokonując analizy i oceny przebiegu badania pilotażowego z trzecioklasistami należy powiedzieć, że wprowadzenie uczniów w tematykę warsztatu wykazało, że jest to niezwykle istotny element zajęć, który umożliwił badanym zrozumienie poleceń w dalszych ćwiczeniach. Kwestią kluczową okazało się wyjaśnienie badanym terminu grupa etniczna. Istota tego pojęcia była pierwotnie dzieciom nieznana i wymagała objaśnienia przez nauczyciela. W celu wytłumaczenia dzieciom pojęcia grupy etnicznej, nauczyciel posłużył się przykładem Romów w Polsce. Wprowadzenie trwało około 
pięciu minut.

Przed rozpoczęciem prezentacji nauczyciel przedstawił uczniom wspomnianą wcześniej pacynkę na którą uczniowie zareagowali w sposób obojętny. Ze względu na brak zainteresowania pacynką przez badanych, nauczyciel nie wykorzystywał jej w dalszej części pilotażu. Tym samym potwierdziły się sugestie niektórych studentów i ostatecznie zrezygnowano z używania pacynki w badaniu zasadniczym.

W trakcie trwania prezentacji multimedialnej uczniowie wykazywali postawę zaangażowania, a także skupienia. Zainteresowanie trzecioklasistów prezentacją multimedialną dotyczyło nie tylko jej strony wizualnej, ale przede wszystkim związanego z nią zadania, które zostało postawione przed dziećmi. Świadczyły o tym liczne komentarze uczniów o charakterze motywującym się nawzajem do wspólnej, wytężonej pracy umysłowej w celu odgadnięcia danego państwa bądź grupy etnicznej na podstawie zaprezentowanych zdjęć. Elementy wizualne również przykuwały uwagę dzieci oraz stanowiły inspirację do podejmowania różnych dyskusji, zadawania pytań, a także dzielenia się swoimi doświadczeniami. Przykładem może być chociażby zainteresowanie uczniów tradycyjnym strojem romskim. Ponadto należy nadmienić, iż zdjęcia umieszczone w prezentacji dostarczały uczniom także i nowej wiedzy, na co wskazują liczne pytania uczniów o nazwę nakrycia głowy noszonego przez Żydów. Nie ulega wątpliwości, że reakcje uczestników podczas tego ćwiczenia dowiodły, iż metoda wywiadu grupowego uzupełniona o metodę wizualizacji jest nie tylko kreatywną, ale i interesującą metodą gromadzenia danych. Ponadto stwarza ona badanym doskonałą możliwość dzielenia się swoimi doświadczeniami. Oczywiście należy mieć na uwadze, że niektórzy uczestnicy mogą stwarzać szczególne problemy w nawiązywaniu kontaktu, co ściśle wiąże się z charakterem oraz temperamentem uczniów. Obecność badacza może także powodować tendencyjność wypowiedzi. Dlatego też niezwykle istotne jest stworzenie przez nauczyciela atmosfery otwartości, wzajemnego zaufania, partnerstwa oraz poczucia, że błąd nie stanowi porażki, a jedynie umożliwia dalszy rozwój.

W obliczu powyższych rozważań należy również pochylić się nad poziomem trudności ćwiczenia polegającego na odgadywaniu nazw danego kraju bądź grupy etnicznej na podstawie zdjęć zamieszczonych w prezentacji. W ocenie uczniów najbardziej pomocne w tym zadaniu okazały się zdjęcia ukazujące tradycyjne stroje określonych narodowości bądź mniejszości etnicznych. Trzecioklasiści poprawnie rozpoznali niektóre $\mathrm{z}$ nich (np. Romów, Brytyjczyków), jednak rozpoznanie większości narodowości ze zdjęć wymagała wsparcia nauczyciela (np. Słowacy, Ukraińcy). Zadanie to charakteryzowało się średnim poziomem trudności i wraz $\mathrm{z}$ wywiadem trwało około piętnastu minut.

Podczas wywiadu, który odbywał się po każdej części prezentacji, uczestnicy byli jeszcze bardziej zaangażowani. Niewątpliwie fakt ten przyczynił się do uzyskania wielu interesujących informacji, które przede wszystkim dotyczyły postrzegania Innego przez uczniów. Mając jednak na uwadze ograniczenia czasowe badania, nauczyciel musiał wykazać się umiejętnością monitorowania oraz sprawnego przeprowadzania dyskusji.

W tym miejscu należy również dodać, że wszyscy badani z nielicznej grupy pilotażowej wyrażali się o innych narodowościach oraz grupach etnicznych w sposób bar- 
dzo kulturalny, pełen szacunku i zainteresowania ich kulturą, obyczajami i tradycjami. Wskazywały na to m.in. takie wypowiedzi jak: „Oni są tacy sami jak my, są po prostu zwykłymi ludźmi”, „Ludzie z innych krajów są ciekawi, mogą nas dużo nauczyć o swojej kulturze”, „Nigdy nie poznałem Roma, ale chętnie zaprosiłbym go na tydzień do swojego domu, żeby nie musiał tak cały czas się tułać. Może ugotowalibyśmy polsko-romski obiad.” Nie ulega wątpliwości, że wypowiedzi uzyskane podczas wywiadu w badaniu zasadniczym stanowią znaczący nośnik informacji o obrazie Innego wśród trzecioklasistów. Szczególnie interesujące może wydawać się również ich zestawienie z wynikami ankiety mierzącej dystans społeczny wobec grup innych kulturowo (w ramach tej samej grupy badanych). Z pewnością porównanie wyników metody sondażowej oraz wywiadu umożliwiłoby ocenę poziomu spójności konstruowanego obrazu Innego wśród badanej grupy, a w związku z tym określenie pola ewentualnych rozbieżności zdania badanych. $\mathrm{W}$ tym miejscu istotne jest również zwrócenie uwagi na proces nieustannego rozważania napływających danych przez badacza, a także ewentualnego stawiania pytań o charakterze analitycznym. Z licznych wypowiedzi uczniów powinny zostać wynotowane te treści, których struktura jest uporządkowana wokół najważniejszych pojęć takich jak np. wątek bądź kontekst problemów i pytań badawczych (Creswell 2013). W trakcie trwania wywiadu podczas badania pilotażowego, nauczyciel starał się dokładnie notować wszystkie wypowiedzi uczniów. Zauważono jednak, że część treści ze sporządzonych notatek nie stanowiły odpowiedzi na pytania zawarte w kwestionariuszu wywiadu, a tym samym nie miały one znaczenia dla poszukiwanych odpowiedzi na postawione problemy oraz pytania badawcze. Należy również nadmienić, iż umiejętność porządkowania treści wypowiedzi uczniów jest niezwykle cenna w kontekście efektywnego wykorzystania czasu badania. Wniosek ten stanowi jednocześnie istotną wskazówkę badawczą, która zostanie wykorzystana podczas badania zasadniczego.

Po przeprowadzonej prezentacji uczniowie byli zaproszeni do wzięcia udziału w kolejnym ćwiczeniu. Na podstawie zadania wymagającego od dzieci napisania skojarzeń dotyczących określonej grupy etnicznej oraz danego kraju i jego mieszkańców uzyskano następujące odpowiedzi:

Wielka Brytania - korona brytyjska, język angielski, moja ciocia

Hiszpania - flamenco

Romowie - Rumunia, kolorowy strój, brak swojego państwa

Słowacja - taniec, Słowenia

Ukraina - koledzy

Wietnam - owoc o nieprzyjemnym zapachu (durian), Natalia (imię znanej uczniom koleżanki z tego kraju), kosze, herbata

Żydzi - jarmułka, Egipt, II wojna światowa 
Uczniowie uznali opisywane ćwiczenie za stosunkowo trudne. Trzecioklasiści wykonali je w ciągu około czterech minut. Nie ulega wątpliwości, że niektóre skojarzenia wymienione przez uczniów mogły stanowić sugerowane odpowiedzi wynikające z określonych wątków rozmowy na temat krajów bądź grup etnicznych podczas prezentacji multimedialnej. Wniosek ten jest istotny dla modyfikacji scenariusza warsztatów, w którym zadanie to powinno znajdować się zaraz po wprowadzeniu uczniów w tematykę warsztatu.

Kolejne ćwiczenie polegało na wcieleniu się trzecioklasistów w rolę dziennikarzy i napisaniu na kartkach pytań bądź przemyśleń skierowanych do danej grupy etnicznej, a także mieszkańców danego kraju. Ze względu na znikomą liczbę pytań zadanych przez uczniów planowany czas pięciu minut na jego wykonanie okazał się zbyt długi. Analizując wyniki omawianego ćwiczenia należy stwierdzić, iż dla badanych prezentowało ono dość wysoki poziom trudności. Wśród pytań znaleźć można następujące: „Ile Wasza Królowa ma Corgów?”, „Dlaczego brytyjscy strażnicy Królowej nic nie mówią i się nie ruszają?”, „Skąd się wzięła korona brytyjska?”, „Czemu Romowie nie mają swojego państwa?”, „Dlaczego Romowie chodzą po różnych krajach?”, „Chcę pomóc Żydom”, „Żydzi, dlaczego nosicie jarmułki?”, „Hiszpanie, czy wiecie, że Ola to imię po polsku?”, „Wietnamczycy, czemu macie śmierdzący owoc?”. Ponadto największa liczba badanych zadała pytanie mieszkańcom Wielkiej Brytanii. W tym miejscu należy zwrócić uwagę na to, że szkoła w której odbywały się badania realizuje zarówno program polski jak i angielski. Stąd może wynikać znacznie większa wiedza badanych dotycząca państwa wyspiarskiego. Fakt ten może stanowić również cenną wskazówkę przy procesie analizy tego ćwiczenia w badaniu zasadniczym. Analiza ta mogłaby również uwzględniać czynnik jakim jest realizowany przez placówkę program bądź rożnego rodzaju działania propagujące edukację międzykulturową np. warsztaty bądź zajęcia dotyczące innych kultur.

Mimo, że uczniowie uznali dwa ostatnie ćwiczenia za niełatwe to jednak wciąż wykazywali oni zapał i determinację w celu wykonania ich na najwyższym poziomie. Ponadto wspomniane zadania w ocenie uczniów były ciekawe i kreatywne na co wskazywały komentarze badanych na ten temat, które kierowali bezpośrednio do prowadzącego badanie.

W zakresie badania jakościowego ostatnią aktywnością, do której zaproszeni byli trzecioklasiści było stworzenie rysunku ukazującego ucznia w wymyślonej sytuacji z Innym. Ćwiczenie to trwało około dziesięciu minut. Uczniowie zareagowali na nie entuzjastycznie. Większość dzieci zwróciła jednak uwagę na zbyt krótki czas przeznaczony na wykonanie ćwiczenia. Mimo iż wszyscy pomyślnie je ukończyli to jednak towarzyszył temu działaniu pośpiech. Biorąc pod uwagę ograniczenie czasowe badania oraz jego główny cel, należy także rozważyć potraktowanie wcześniejszego ćwiczenia, tj. wcielenia się uczniów w rolę dziennikarzy, jako opcjonalnego w badaniu zasadniczym bądź jego całkowite usunięcie ze scenariusza warsztatu. Pilotaż wykazał również, że wyniki uzyskane za pomocą metody wywiadu zogniskowanego uzupełnionego o metodę wizualizacji oraz wykonanie pracy plastycznej w zestawieniu z pozostałymi ćwiczeniami stanowiły podstawowe źródło istotnych danych dla celu badania.

Na podstawie analizy rysunków trzecioklasistów należy powiedzieć, że wszyscy 
badani biorący udział w pilotażu ukazali relację z przedstawicielami innego kraju w kontekście wspólnie spędzanego czasu wolnego. Była to przede wszystkim zabawa na świeżym powietrzu do której zaliczymy: granie w piłkę nożną, tańczenie, jeżdżenie na nartach, zabawy na placu zabaw, a także piknik na świeżym powietrzu. Należy dodać, że uzyskane wyniki z badania zasadniczego odnoszące się do form spędzania czasu z kolegami i koleżankami z innych krajów mogą być szczególnie interesujące w kontekście zestawienia ich z wynikami ankiety.

W zakresie badania ilościowego zadaniem trzecioklasistów było wypełnienie kwestionariusza ankiety opartej na skali Bogardusa dystansu społecznego, który widoczny jest poniżej.

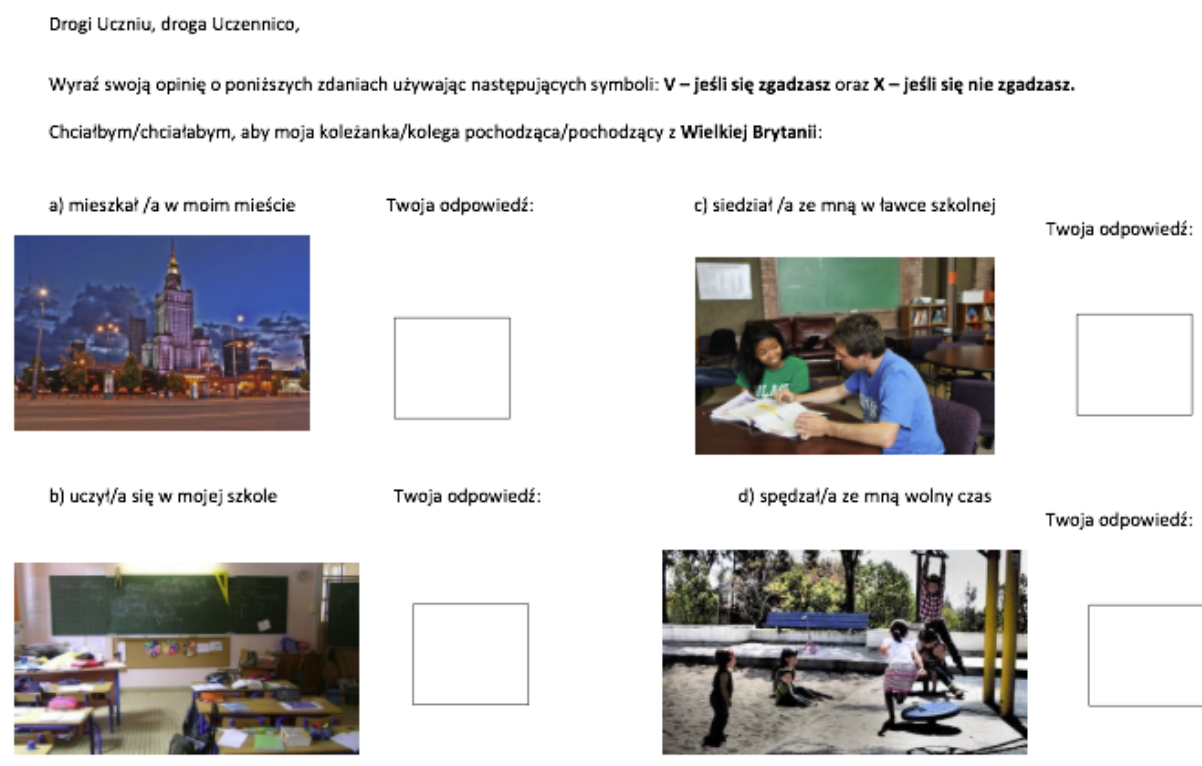

Rycina 2.

Źródło: autorski kwestionariusz ankiety oparty na skali Bogardusa dystansu społecznego

Zadaniem badanych było wyrażenie swojej opinii poprzez postawienie jednego z dwóch symboli przy czterech obrazkach symbolizujących poszczególne sfery: mikrospołeczną, makrospołeczną, prywatną oraz intymną. Symbol V oznacza zgodę, a symbol X - niezgodę. Powyżej zamieszczony kwestionariusz ankiety dotyczył osób pochodzących z następujących narodowości bądź grup etnicznych:

Wielkiej Brytanii

Hiszpanii

osób będących Romami

Słowacji

Ukrainy 


\section{Wietnamu}

osób będących Żydami

Na wyjaśnienie instrukcji wypełniania ankiety nauczyciel przeznaczył około minutę, natomiastuczniowieukończylijąwciąguokołopięciuminut.Brakpytańzestronyuczniów o sposób jej uzupełnienia oraz sprawne przeprowadzenie tej części badania pozwala stwierdzić, że uczniowie nie mieli problemu ze zrozumieniem instrukcji kwestionariusza ankiety. Ponadto została ona zaprojektowana $\mathrm{w}$ taki sposób, aby zminimalizować szansę pomyłki przy jej wypełnianiu. Na przejrzystość i czytelność kwestionariusza wpływa nie tylko fakt, iż miejsce na opinię o każdej grupie innej kulturowo znajduje się na osobnej stronie, ale również to, że zawiera on fotografie ilustrujące omówione w poprzednim rozdziale podstawowe sfery życia. Niewątpliwie dzięki zestawieniu wyników ujęcia ilościowego z wynikami ujęcia jakościowego w zakresie badania zasadniczego możemy uzyskać szerszą perspektywę problemu. Ponadto w kontekście analizy danych ilościowych można również rozważyć odniesienie się do badań CBOS z poprzednich lat, które dotyczyły stosunku Polaków do innych narodowości. Zestawienie wyników badań CBOS z wynikami omawianej ankiety może wydawać się interesujące, ponieważ stosunek uczniów do wybranych narodowości może, ale nie musi pokrywać się w pełni ze stosunkiem dorosłych Polaków.

\section{PODSUMOWANIE}

Celem podjętego badania pilotażowego była analiza oraz ocena przydatności metod i narzędzi badawczych. Reakcje, komentarze oraz zaangażowana postawa uczniów świadczyły o tym, że zajęcia warsztatowe zainteresowały grupę badanych. Podczas badania jakościowego można było zaobserwować, że uczniowie bardzo chętnie dzielili się swoimi spostrzeżeniami oraz doświadczeniami. Przykładem będzie metoda wywiadu zogniskowanego uzupełnionego o metodę wizualizacji. Na otwartość oraz pozytywną motywację do wypowiedzi respondentów przyczyniło się niewątpliwie zadbanie badacza o stworzenie atmosfery pełnej wzajemnego szacunku, sympatii i zrozumienia, a także szczerego zainteresowania wypowiedziami uczniów. Kwestionariusz wywiadu jako narzędzie badawcze charakteryzował się pytaniami o charakterze otwartym. Pytania te były krótkie, zwarte, jasne i zrozumiałe dla uczestników badania. Podobne wnioski można wysnuć z zastosowanej w pilotażu metody sondażowej. Jej narzędziem badawczym był kwestionariusz ankiety badającej dystans społeczny uczniów wobec wybranych narodowości oraz grup etnicznych. Ankieta była zaprojektowana w taki sposób, że tworzyła zwartą i konsekwentną całość, a to z kolei wpłynęło na fakt, że uczniowie doskonale rozumieli treść kierowanych do nich pytań.

Pilotaż wykazał, że jedna godzina lekcyjna to czas, który wystarcza na zrealizowanie scenariusza warsztatu. Dla uczniów niełatwe okazały się ćwiczenia, które wymagały od nich formułowania pytań do przedstawicieli innych krajów bądź grup etnicznych, a także napisania skojarzeń z nimi związanych. Pomimo tego, trzecioklasiści 
podczas wspomnianych ćwiczeń byli skupieni oraz pełni zapału do pracy. Biorąc pod uwagę fakt, że podczas wywiadu dzieci udzielały wielu istotnych dla celu badania informacji oraz zwróciły uwagę na zbyt krótki czas przeznaczony na wykonanie rysunku ukazującego ich z koleżanką bądź kolegą z innego kraju lub grupy etnicznej, można rozważyć rezygnację z ćwiczenia dotyczącego wcielania się w rolę dziennikarzy w badaniu zasadniczym. Pozwoliłoby to m.in. na wydłużenie czasowe wywiadu z uczniami, a tym samym uzyskanie jak największej liczby wypowiedzi badanych stanowiących istotne źródło odpowiedzi na problemy oraz pytania badawcze. Warto dopowiedzieć, że ze względu na liczne wypowiedzi badanych oraz dalsze ćwiczenia uwzględnione w scenariuszu zajęć, wywiad musiał zostać przeprowadzony w sposób zarówno dynamiczny jak i efektywny. W kontekście ograniczenia czasowego badania należy zwrócić uwagę na to, że pilotaż pozytywnie zweryfikował pomysł zmniejszenia w badaniu liczby omawianych państw i grup etnicznych z dwunastu do siedmiu.

Opisywane tutaj badanie pilotażowe przeprowadzone na pięcioosobowej grupie trzecioklasistów nie pozwala wyciągać znaczących statystycznie wniosków. Potwierdza ono jednak zasadność przeprowadzenia tą metodą badań na większej grupie dzieci.

Niewątpliwie tego typu badania mogą przyczynić się do poprawy efektywności pracy z dziećmi w obszarze uwrażliwiania na inność. Chodzi przede wszystkim o wszelkie działania praktyczno-edukacyjne. W tym miejscu warto nawiązać do edukacji międzykulturowej, która akcentuje w swoich założeniach dialog, przenikanie się kultur, szacunek wobec różnic, ich współpracę oraz współdziałanie przy jednoczesnym zachowaniu odrębności. Różnicę kulturową postrzega się tutaj jako zasadniczą cechę jednostki, która ma określone znaczenie oraz wartość. Takie postrzeganie kwestii różnic przygotowuje jednostkę do życia w świecie różnych kultur. Podejście międzykulturowe wyzbywa się narzucania innym swojej kultury i dąży do traktowania wszystkich grup mniejszościowych oraz ich kultur jako równorzędnych (Grzybowski 2007). W tym miejscu można przywołać wypowiedź jednego z badanych, który stwierdził, że „wszystkie dzieci są takie same”. Wypowiedź tę można zestawić i uzupełnić z wypowiedzią ghańskiego sekretarza generalnego Organizacji Narodów Zjednoczonych. Powiedział on, że uniwersalność praw człowieka wynika nie tylko z tego, że są one zakorzenione w każdej kulturze i tradycji, ale także zaakceptowane przez 185 Członków ONZ. Tym samym zarówno dzieci jak i dorośli są objęci prawną ochroną przed różnymi formami dyskryminacji bądź kar z powodu wyrażanych poglądów, przekonań religijnych, a także statusu prawnego. Powszechne uznawanie praw człowieka powinno być tym samym uznawane nie tylko teoretycznie, ale i praktycznie jako pożądany standard o charakterze idealnym (Balicki 2015).

Nie ulega wątpliwości, że przekonanie to w obliczu coraz bardziej nasilającego się zjawiska wielokulturowości powinna rozbudzać w swoich wychowankach polska szkoła. Wiele badań wykazało jednak, że nie przygotowuje ona swoich uczniów do funkcjonowania w świecie wielokulturowym. W tym kontekście działania szkół charakteryzują się powierzchownością, której efektem jest to, że standardy społeczne ulegają znacznemu obniżeniu. Formy doskonalenia i kształcenia zawodowego nauczycieli, mają charakter doraźny, a wiedza przyswajana przez nauczycieli najczęściej jest wie- 
dzą potoczną (Dobrowolska 2015). Wynika to m.in. z braku przygotowania nauczycieli już na szczeblu kształcenia akademickiego. Według Barbary Dobrowolskiej nauczycielom brakuje wiedzy socjologicznej, antropologicznej oraz psychologicznej (Dobrowolska 2015). Ponadto badania Joanny Talewicz-Kwiatkowskiej i Małgorzaty Kołaczek wykazały, że w polskich szkołach występują praktyki dyskryminacyjne (Dobrowolska 2015). Obcymi najczęściej nazywani są cudzoziemcy, którzy niejednokrotnie są wyśmiewani bądź traktowani jak margines społeczny. Najczęściej wynika to z odmiennego wyglądu, a także braku umiejętności posługiwania się językiem polskim. Biorąc pod uwagę powyższe rozważania należy podkreślić, że ważnym zadaniem szkoły jest walka ze stereotypami odmienności kulturowej. Niektórymi z wymiarów walki w tym zakresie będzie m.in. zdobywanie wiedzy oraz kompetencji międzykulturowych przez nauczycieli poprzez udział w różnego rodzaju szkoleniach i warsztatach, tłumaczenie uczniom kontekstów określonych różnic kulturowych w ramach przeciwdziałania stereotypom, a także selektywne wybieranie treści edukacyjnych z podręczników oraz praktykowanie edukacji międzykulturowej mającej na celu uwrażliwianie na Inność. Należy także podkreślić, że kształcenie międzykulturowe to nie tylko zdobywanie wiedzy o innych kulturach, ale także rozwój umiejętności komunikacyjnych oraz empatii (Kulka 2010).

\section{BIBLIOGRAFIA}

Badowska, Mariola. 2015. Różnorodność kulturowa uczniów wyzwaniem dla współczesnej szkoły. „Kultura-Społeczeństwo-Edukacja” 1/7: 181.

Balicki, Ryszard i Patrycja Mateusz-Protasiewicz. 2015. Prawo dzieci migrantów. W: L.S. Stadniczeńko (red.). Konwencja o prawach dziecka. Warszawa, s. 283-284.

Banks, Marcus. 2013. Materiały wizualne w badaniach jakościowych. Tłum: Paweł Tomanek. Warszawa: Wydawnictwo Naukowe PWN.

Barwiński, Marek. 2016. Wielokulturowość we współczesnych polskich badaniach geograficznych i edukacji geograficznej - zarys problematyki. „Przegląd Geograficzny” 88(2): 149.

Berry, John W. i David Sam. 2013. Accomodating cultural diversity and achieving equity. An introduction to psychological dimensions of multiculturalism. "European Psychologist” 18 (3), 151-157.

Creswell, John W. 2013. Projektowanie badań naukowych. Metody jakościowe, ilościowe i mieszane. Kraków: Wydawnictwo Uniwersytetu Jagiellońskiego.

Dąbrowa, Ewa i Urszula Markowska-Manista. 2018. Przygotowanie nauczycieli i pedagogów w zakresie edukacji międzykulturowej - prezentacja projektu badawczego. „Edukacja międzykulturowa” 1(8): 169.

Dobrowolska, Barbara. 2015. Nowe zadania szkoły i nauczycieli w społeczeństwach wielokulturowych. Miejsce wielo- i międzykulturowości w edukacji. W: Młodzież w społeczeństwie wielokulturowym. Od małej ojczyzny do globalnego świata, (red.) Daniel Wiśniewski. Warszawa: Difin SA. 
Gromadzka, Beata. 2016. Szkoła-nauczyciel-grupa w środowisku zróżnicowanym kulturowo na przykładzie uczniów romskich w polskich szkołach. „Polonistyka. Innowacje.” 4: 127.

Grzeszkiewicz-Radulska, Katarzyna. 2012. Metody badań pilotażowych. „Acta Universitatis Lodziensis, Folia Sociologica” 42: 113.

Grzybowski, Przemysław Paweł. 2007. Edukacja w warunkach zróżnicowania kulturowego. „Przegląd Pedagogiczny” 18(1): 57-68.

Jasińska-Kania, Aleksandra i Katarzyna M. Staszyńska. 2009. Diagnoza postaw młodzieży województwa podlaskiego wobec odmienności kulturowej. Białystok: Urząd Marszałkowski Województwa Podlaskiego.

Klus-Stańska, Dorota i Maria Szczepska-Pustkowska. 2009. Pedagogika wczesnoszkolna - dyskursy, problemy, rozwiązania. Warszawa: Wydawnictwa Akademickie i Profesjonalne.

Kozerska, Agnieszka. 2013. Wywiad narracyjny w badaniach nad uczeniem się człowieka dorosłego w kontekście historii jego życia. „Edukacja ustawiczna dorosłych” 2(18): 29-35. http://cejsh.icm.edu.pl/cejsh/element/bwmeta1.element.desklight-bad71026-352e-475e-b89b-67bbfbd512c5/c/Wywiad_narracyjny_w_badaniach.pdf [Dostęp: 19-09-2019].

Kubiszyn, Marta. 2007. Edukacja wielokulturowa w środowisku lokalnym. Toruń: Wydawnictwo „Adam Marszałek”.

Kulka, Barbara. 2010. Przełamywanie uprzedzeń i stereotypów narodowych $w$ edukacji polonistycznej (w świetle wybranych programów kształcenia i podręczników). W: Oswajanie Inności w Edukacji Polonistycznej, (red.) B. Myrdzik, E. Dunaj. Lublin: Wydawnictwo Uniwersytetu Marii Curie-Skłodowskiej.

Kwiatkowska, Anna. 2019. Wielokulturowość w ujęciu interdyscyplinarnym. Warszawa: Wydawnictwo Naukowe PWN SA i Instytut Psychologii Akademii Nauk.

Markowska-Manista, Urszula. 2016. Walka ze stereotypami odmienności kulturowej -szkolne i pozaszkolne pola bitewne. W: M. Dudzikowa i S. Jaskulska „Twierdza. Szkoła w metaforze militarnej. Co w zamian?”. Warszawa: Wolters Kluwer.

Markowska-Manista, Urszula i Ewa Dąbrowa. 2016. Uczeń jako Inny w polskiej przestrzeni edukacyjnej - krytyczne spojrzenie na szkołę w kontekście zróżnicowania kulturowego. „Edukacja Międzykulturowa” 5: 37.

Markowska-Manista, Urszula i Barbara Pasamonik (red.). 2017. Kryzys migracyjny. Perspektywa pedagogiczno-psychologiczna. Tom II. Warszawa: Wydawnictwo Akademii Pedagogiki Specjalnej.

Mihułka, Dorota. 2008. Dialog interkulturowy jako piąta sprawność na lekcji języka obcego. „Języki Obce w Szkole” 2: 14.

Nowak-Łojewska, Agnieszka. 2017. Dziecięce konstrukcje świata w rozmowach z dorosłymi. „Problemy Wczesnej Edukacji” 13: 57.

Szostak-Król, Katarzyna. 2004. Inny bliski i daleki - rozważania o potrzebie edukacji międzykulturowej we wczesnej edukacji dziecka. W: A. Klimowicz. Edukacja międzykulturowa. Warszawa: Wydawnictwa CODN.

Szplit, Agnieszka i Zuzanna Zbróg. 2012. Projekty edukacyjne jako sposób realizacji edukacji wielokulturowej dzieci $w$ wieku przedszkolnym i wczesnoszkolnym. „Problemy 
wczesnej edukacji” 8: 47.

Welskop, Wojciech. 2014. Socjologiczne ujęcie Innego w szkole. „Edukacja Humanisyczna” $1: 210$.

Wojnicz, Piotr. 2014. Prawne aspekty integracji imigrantów w Unii Europejskiej w kontekście wielokulturowości. „Civitas et Lex” 4: 36, [Dostęp: 14-09-2019] <http://yadda. icm.edu.pl/yadda/element/bwmeta1.element.desklight-fed7b7ca-fa72-437d-a8e6-10fae2c002b6>.

\title{
Analysis and evaluation of research methods and tools: report from the pilot study on the image of the Other constructed by Polish third-graders
}

\begin{abstract}
The article presents an analysis and evaluation of research tools used in a pilot study of an image of Other created by third grade students. The image is tightly connected to determining children's approach towards Others, for example by estimating their social distance to culturally distinct groups. The research was of mixed type containing both qualitative and quantitative methods. Furthermore, the article's goal is to show the important question of how lower grade students view culturally distinct Others in a wider context of multiculturalism as a challenge for modern Polish education.
\end{abstract}

KEYWORDS: Image of other, early childhood education, multiculturalism, challenges of modern education, pilot study 